\title{
RANCANG BANGUN APLIKASI PENCARIAN BENGKEL, CUCI MOTOR DAN TUKANG KUNCI TERDEKAT BERBASIS MOBILE
}

\author{
(Mobile-Based Application to Search Motorcycle Workshop, Motorcycle Wash and \\ Key Duplicate)
}

\author{
Liza Yuliana Khairani, Ario Yudo Husodo*, Fitri Bimantoro \\ Dept Informatic Engineering, Mataram University \\ Jl. Majapahit 62, Mataram, Lombok NTB, INDONESIA \\ Email: lizayuliana2257@gmail.com, ario@ti.ftunram.ac.id, bimo@unram.ac.id
}

\begin{abstract}
As the number of motorcycles users are increasing in Indonesia, this will also increase the problems that they have to deal with. Furthermore, the user of the smartphone is also increasing as well, so that it can be a media to connect the motorcycle owners with the workshop to make the problem solving becoming a lot easier. Therefore, based on that matters, we can develop a mobile-based application in order to help the users to cope easier with their problems. The application can help the user to find the nearest workshop and motorcycles wash, in order to solve the problems such as dirty motorcycle, flat tire, the tire burst or oil change. This application was designed to provide some information about the nearest workshop, the route to the workshop, reveal the comments and send a message to the owner of the workshop. Meanwhile, the owner of the workshop can see the comments about their workshop, receive an order and see the customer location. The testing technique which was used in this research were blackbox and MOS testing. The result of blackbox testing showed that all features can be run as planned.
\end{abstract}

Keywords: Workshop location, Motorcycles, Smartphone, Order Service, Blackbox Testing.

*Penulis korespondensi

\section{Pendahuluan}

Pada saat ini, kendaraan bermotor khususnya sepeda motor dianggap menjadi kebutuhan dasar untuk mengatasi masalah transportasi. Selain mudah digunakan, faktor efisiensi berkendara di tengah kemacetan menjadi penunjang tambahan dengan semakin banyaknya masyarakat yang memilih membeli sepeda motor. Pada tahun 2017, setidaknya jumlah motor yang terdata di Indonesia diketahui dari situs data BPS berjumlah 113.030.793[1]. Dibanding dengan jumlah motor pada tahun 2015 yaitu 98.881 .267 dan pada tahun 2016 yaitu 105.150.082, pertambahan 6 hingga 7 juta unit pertahunnya, terlihat bahwa peningkatan jumlah pemilik sepeda motor naik dengan pesat setiap tahunnya.

Dengan pesatnya pertambahan pengguna kendaraan motor maka bertambah pula pengendara yang mengalami berbagai kendala dengan kendaraan motor tersebut, mulai dari masalah yang paling remeh yakni motor kotor karena tidak sempat memandikan motor tersebut, lupa atau tidak sempat mengganti oli motor secara berkala, ban kempes saat sedang berkendara, kehilangan kunci motor dan tidak memiliki serep, ban pecah bahkan motor mati dan mogok secara tiba-tiba sehingga pengendara harus membawa kendarannya ke bengkel terdekat.

Untuk pengendara yang mengalami permasalahan saat berkendara, biasanya hanya menuntun motor yang bermasalah tersebut secara acak saat tidak mengetahui secara pasti letak dari bengkel terdekat atau saat berada di lingkungan yang tidak dikenalinya secara pasti, pengendara pun tidak mengetahui berapa jarak yang harus ditempuh sambil menuntun sepeda motornya ke bengkel terdekat, sering kali pengendara bertanya pada warga sekitar untuk mengetahui lokasi bengkel motor terdekat. Namun tidak sedikit pengendara yang malah bertambah bingung karena kurang jelasnya informasi yang didapatkan saat bertanya pada warga sekitar.

Di sisi lain, pengguna smartphone juga terus bertambah pesat di berbagai lapisan masyarakat, seiring dengan berkembangnya aplikasi yang menunjang smartphone tersebut, bahkan smartphone sendiri seperti menjadi kebutuhan pokok untuk menunjang berbagai aktivitas sehari-hari. Berbagai aplikasi penyedia jasa mulai muncul dan berkembang pesat serta memiliki banyak pengguna, mulai dari 
penyedia jasa ojek online, taxi online hingga jasa pengantaran barang dagangan pasar tradisional online. Dengan meningkatnya pengguna smartphone dan pengguna motor, maka dapat dirancang sebuah aplikasi penyedia jasa yang dikhususkan untuk pengendara motor. Adapun fitur utama yang dirancangkan dan khusus untuk service motor, yakni pengguna dapat melihat ketersediaan bengkel di sekitar lokasi pengguna motor saat ini serta service panggilan dimana nantinya montir atau pihak dari penyedia jasa akan mendatangi lokasi pihak pengguna motor yang sedang mengalami kendala pada kendaraannya saat sedang melakukan perjalanan.

\section{TINJAUAN PUSTAKA}

Dalam jurnal yang berjudul Sistem delivery order berbasis android pada AADS Yogyakarta melakukan penelitian kepada layanan delivery order di Daerah Istimewa Yogyakarta (DIY) dimana transaksi pemesanan menggunakan layanan telepon dan dilanjutkan dengan pembayaran tunai ditempat si pembeli. Sedangkan pada proses pengantaran pesanan dikirimkan oleh pengantar yang belum begitu mengetahui lokasi si pembeli. Sehingga pengantar mengalami sedikit kesulitan dalam melakukan pencarian lokasi pembeli baru sehingga dibuatlah aplikasi delivery order dimana petugas yang mengantarkan makanan yang dipesan dapat melihat lokasi dari pemesan itu sendiri, sehingga tempat pengantaran yang dituju jelas. dengan fitur yang disediakan oleh sistem untuk melacak atau mengetahui lokasi pemesan, maka siapa saja dapat menjadi pengantar makanan yang telah di pesan, tidak diperlukan lagi tenaga ahli yang mengetahui seluk beluk detail dari setiap lokasi di Daerah Istimewa Yogyakarta[2].

Pada jurnal yang berjudul Membangun Aplikasi Layanan Pencarian Lokasi Kuliner Terdekat Di Yogyakarta Berbasis Android, pengembang membangun sebuah aplikasi berbasis android dimana terdapat 2 katagori pengguna yaitu admin dan pengguna biasa. Untuk admin sendiri terdapat beberapa fitur yang disediakan antara lain tambah lokasi untuk menambah lokasi kuliner baru secara manual, daftar lokasi untuk melihat lokasi-lokasi yang pernah dimasukkan admin ataupun lokasi yang dimasukkan oleh pengguna biasa dan disetujui oleh admin, lokasi from user adalah halaman berisi data lokasi kuliner yang dikirimkan oleh pengguna biasa dimana admin dapat menolak ataupun menerima lokasi yang dikirimkan oleh pengguna biasa dan terakhir fitur edit lokasi yang merupakan fitur untuk memperbaharui data lokasi yang telah terdaftar. Sedangkan fitur untuk pengguna aplikasi biasa, dapat melakukan pencarian lokasi tempat kuliner dengan memasukkan keyword tertentu, mencari dengan katagori tertentu atau mencari dengan melihat rekomendasi tempat kuliner berdasarkan rating yang diberikan serta dapat mencari lokasi kuliner terdekat dari tempatnya sekarang. Pengguna juga dapat mengajukan lokasi kuliner terbaru yang nantinya akan diproses oleh admin[3].

Dalam sebuah peneilitian, ditampilkan list atau daftar bengkel resmi yang berada di kota palembang yang disusun secara acak, dimana pengguna dapat melakukan scroll menu untuk melihat seluruh data yang tertampung pada aplikasi. Aplikasi juga menyediakan fitur pencarian lokasi bengkel tertentu dan fitur pencarian bengkel terdekat dari lokasi dengan menu yang terpisah. Pihak pengembang telah mengumpulkan data-data bengkel resmi dari berbagai merk motor sehingga memudahkan pengguna untuk mengetahui nama bengkel resmi yang ada di Palembang[4].

Dalam jurnal yang berjudul Perancangan Aplikasi Pencarian Bengkel Di Kabupaten Gunungkidul Menggunakan Global Potitioning System (GPS) Berbasis Android, melakukan perancangan aplikasi dengan tujuan membantu para wisatawan Gunungkidul untuk mengetahui letak bengkel secara cepat dan tepat saat kendaan meraka mengalami kendala atau kerusakan. Bagi wisatawan yang belum mengenal daerah Gunungkidul tentu akan merasa kesulitan untuk mencari lokasi bengkel jika dalam perjalanan mengalami kerusakan kendaraan. Umumnya mereka bertanya kepada orang di sekitar wilayah tersebut untuk memperoleh informasi bengkel terdekat, namun cara tersebut kurang efektif dan tentunya membutuhkan waktu yang lama. Maka dibuatlah sebuah aplikasi berbasis mobile Android untuk memudahkan pengguna untuk memperoleh informasi bengkel terdekat di Gunungkidul, seluruh bengkel yang telah terdaftar dapat terlihat lokasinya pada aplikasi saat memilih fitur my location, lalu jika memilih salah satu marker yang ada pada sistem, sistem akan langsung menunjukkan arah menuju marker tersebut. Namun pada aplikasi yang dibuat, tidak terdapat fitur pencarian bengkel, jadi pengguna hanya diberi fitur melihat lokasi bengkel dan jalan menuju bengkel tersebut, serta panduan bagaimana menggunakan aplikasi tersebut[5].

Pada Penelitian yang dilakukan, dibuat sebuah halaman web responsif yang digunakan untuk mencari keberadaan bengkel mobil disekitar pengguna khusus 
kota Semarang. Pada halaman web tersebut pengguna dapat mencari lokasi bengkel yang ada disekitar lokasinya saat ini, terdapat input field berupa radius dan jenis bengkel yang dapat diisi oleh pengguna. Setelah bengkel ditemukan, pengguna dapat melihat detail dan rute ke arah bengkel tersebut. Terdapat admin pad website yang memiliki wewenang untuk mengolah data bengkel ayng terdaftar[6].

Dalam sebuah penelitian yang, dilakukan pengembangan terhadap sebuah aplikasi android yang memuat informasi mengenai lokasi dari bengkel resmi mobil mazda, dimana informasi lokasi itu sendiri diambil melalui website resmi milik mazda Indonesia. Penelitian yang Berjudul Aplikasi Sistem Informasi Geografis Untuk Pencarian Bengkel Mobil Mazda Di Jakarta Berbasis Android ini memuat beragam fitur diantaranya aplikasi dapat memberikan list bengkel mazda kepada pengguna dan melakukan estimasi jarak antara pengguna saat ini dengan bengkel, aplikasi juga dapat memunculkan data detail tentang bengkel tersebut dan menunjukkan lokasi dan rute ke arah bengkel tersebut. Aplikasi juga memuat tips berkendara dan merawat mobil mazda serta list produk mazda yang yang ada dipasaran. Pada aplikasi terdapat menu tombol darurat seperti dealer mazda, ambulans, polisi, pemadam kebakaran dan jasa derek mobil. Tujuan aplikasi ini dibuat agar memudahkan para pengendara mazda untuk menemukan bengkel resmi dengan memanfaatkan smartphone android yang mereka miliki[7].

Penelitian dengan Judul Aplikasi Android Untuk Pencarian Lokasi Tempat Ibadah Di Wilayah Bekasi, dimana dalam aplikasi pengguna dapat melakukan pencarian tempat ibadah seperti pencarian lokasi untuk masjid dan gereja dan ada di daerah Bekasi. Pada aplikasi, pengguna akan ditunjukkan rute menuju lokasi tempat ibadah yang diinginkan dari lokasinya saat ini. Data dari aplikasi ini sendiri diinputkan oleh penulis[8].

Pada sebuah penelitian, dirancang sebuah aplikasi android untuk menampilkan list dan peta dari bengkel AHASS Honda yang berada di kota Semarang. Hasil dari penelitian berupa sebuah aplikasi android yang dapat digunakan untuk melihat lokasi dan detai dari bengkel AHASS honda. Untuk tampilan dalam bentuk list, diberikan informasi berupa nama bengkel, alamat dan nomor telepon dari setiap bengkel. Sedangkan untuk tampilan dalam bentuk map, diberi tampilan berupa persebaran bengkel tersebut pada kota Semarang. Terdapat pula halaman navigasi, dimana pada halaman tersebut ditampilkan navigasi menuju bengkel AHASS yang dinginkan oleh pengguna[9].
Aplikasi sistem informasi geografis bengkel di Kota Denpasar berbasis android merupakan aplikasi yang bertugas untuk menampilkan lokasi-lokasi bengkel di Kota Denpasar. Lokasi bengkel tersebut ditampilkan pada kanvas peta yang menggunakan Google Maps API V2 dalam bentuk marker. Marker selanjutnya menampilkan informasi dari bengkel dengan menggunakan info window. Administrator memiliki hak untuk melakukan pengaturan pada sistem informasi geografis bengkel meliputi penambahan lokasi bengkel, penambahan jenis jasa, penambahan jenis kategori, penambahan jenis spare part, penambahan user, dan menampilkan lokasi bengkel di peta[10].

\subsection{Dasar Teori}

\subsubsection{Bengkel}

Bengkel memiliki arti tempat memperbaiki mobil, sepeda ataupun motor. Bengkel otomotif adalah tempat dimana kendaraan diperbaiki oleh teknisi atau tenaga mekanik. Bengkel repair shop melakukan pekerjaan seperti perbaikan mesin kendaraan, rem, knalpot, transmisi, ban, kaca mobil dan penggantian oli. Bengkel body shop melakukan pekerjaan seperti perbaikan cat terhadap goresan, lecet, dan penyok terhadap kerusakan kendaraan serta kerusakan yang disebabkan oleh tabrakan dan kecelakaan besar[11].

\subsubsection{Location based service (LBS)}

Location Based Service (LBS) merupakan sebuah layanan informasi yang dapat diakses dengan perangkat bergerak melalui jaringan dan mampu menampilkan posisi secara geografis keberadaan perangkat bergerak tersebut. LBS dapat berfungsi sebagai layanan untuk mengidentifikasi lokasi dari seseorang atau suatu objek tertentu, dan juga dapat beraksi aktif terhadap perubahan entitas posisi sehingga mampu mendeteksi letak objek dan memberikan layanan sesuai dengan letak objek yang telah diketahui tersebut. Pada teknologi LBS berbasis jaringan seluler, penentuan posisi sebuah peralatan komunikasi bergerak ditentukan berdasarkan posisi relatif peralatan tersebut terhadap lokasi BTS (Base Transceiver Station)[12].

\subsubsection{Google maps}

Google Maps adalah layanan gratis yang diberikan oleh Google dan sangat popular. Google Maps adalah suatu peta dunia yang dapat kita gunakan untuk melihat suatu daerah. Dengan kata lain, Google Maps merupakan suatu peta yang dapat dilihat dengan menggunakan suatu browser. Pengguna dapat 
menambahkan fitur Google Maps dalam web yang telah dibuat atau pada blog yang berbayar maupun gratis sekalipun dengan Google Maps API. Google Maps API adalah suatu library yang berbentuk JavaScript. Dengan menggunakan Google Maps API, maka dapat menghemat waktu dan biaya untuk membangun aplikasi peta digital yang handal, sehingga dapat fokus hanya pada data-data yang akan ditampilkan. Dengan kata lain, hanya membuat suatu data sedangkan peta yang akan ditampilkan adalah milik Google sehingga tidak dipusingkan dengan mambuat peta suatu lokasi, bahkan dunia.

\section{Metode Penelitian}

\subsection{Metode Pengembangan Sistem}

Pengembangan sistem yang digunakan pada penelitian Rancang bangun aplikasi pencarian bengkel terdekat yaitu model waterfall.

\subsection{Analisa Kebutuhan}

Pada tahan analisa kebutuhan, tahap ini dilakukan analisa pada lapangan dengan cara menyebar beberapa kuisioner dan bertanya secara langsung kepada pihak bengkel sebagai penyedia jasa dan pengendara motor sebagai pemohon sehingga sekiranya kebutuhan sistem dapat dirangkum secara optimal

\subsubsection{Pengumpulan data}

Pada tahapan ini, pengembang mencoba melakukan survey dengan menyebar beberapa kuisioner kepada bengkel dan pemilik motor untuk mendapat data-data yang akan dipakai dalam aplikasi seperti contohnya seperti fitur apa saja yang sekiranya diinginkan oleh pihak bengkel sendiri jika aplikasi dibangun dan tambahan fitur lainnya yang melengkapi aplikasi tersebut.

Dari penyebran kuesioner diketahui bahwa ratarata pemilik motor menggunakan smartphone android, jenis kerusakan motor yang sering dijumpai antara lain, ban kempes, ban pecah, motor mati saat berkendara dan motor tidak bisa menyala saat dihidupkan. Sedangkan rancangan fitur yang diinginkan antara lain cari penyedia jasa dan bisa didatangi oleh penyedia jasa saat dibutuhkan.

Untuk penyedia jasa sendiri, kebanyakan service yang disediakan yaitu ganti oli, pompa ban, tembel ban dan ganti spare part.

\subsubsection{Pendifinisian kebutuhan sistem}

Kebutuhan sistem didasarkan dari tujuan mengapa sistem dibuat, harus sesuai dan tujuan dapat dipenuhi secara tepat. Kebutuhan sistem didapatkan dari apa yang menjadi kebutuhan utama user nantinya yakni: a. Aplikasi mampu menampilkan lokasi penyedia jasa yang berada si sekitar lokasi pengguna motor yang menggunakan aplikasi.

b. Dalam aplikasi, pengguna motor dapat mengirim pesan kepada montir yang berisi lokasinya saat itu.

c. Pada aplikasi, terdapat fitur kirim komentar terhadap bengkel, agar pengguna lainnya lebih mudah menentukan bengkel yang akan digunakan.

d. Aplikasi mampu menampilkan rute yang sebaiknya dilalui ke arah penyedia jasa jika pengguna motor hanya ingin mengetahui lokasi penyedia jasa terdekat.

e. Pendefinisian Kebutuhan User

Pendefinisian kebutuhan user adalah mendefinisikan dan menganalisis berbagai kebutuhan user yang akan dipenuhi oleh sistem yang akan dibangun. Berbagai kebutuhan user dapat didefinisikan dalam rincian seagai berikut:

a. Penyedia jasa

1. Sistem mampu menunjukkan lokasi pengguna motor yang mengirim pesanan.

2. Sistem mampu menerima pesan permintaan dari pengguna motor

3. Sistem dapat menampilkan komentar sebagai bahan pertimbangan perbaikan pelayanan bengkel

4. Sistem mampu menunjukkan detail pesanan dari pihak pengguna motor.

b. Pengguna Motor

1. Sistem mampu menunjukkan lokasi penyedia jasa yang berada di sekitar lokasi pengguna motor.

2. Sistem mampu menunjukan rute ke arah salah satu bengkel yang dipilih oleh pengguna motor.

3. Sistem mampu menunjukkan rute menuju penyedia jasa yang diinginkan.

4. Sistem mampu mengirimkan pesan permintaan kepada pihak penyedia jasa untuk mendatangi pihak pengguna motor.

5. Sistem dapat menampilkan komentar mengenai penyedia jasa sebagai bahan pertimbangan saaat pengguna motor memilih salah satu penyedia jasa.

c. Admin

1. Sistem dapat menunjukkan seluruh bengkel yang telah signup untuk selanjutnya 
diproses admin, apakah pengajuan di setujui atau ditolak

\subsection{Perancangan Arsitektur Sistem}

Perancangan arsitekur dijadikan sebagai dasar dalam pengembangan sistem yang akan dibuat. Perancangan arsitektur menggambarkan bagaimana aplikasi yang diakses oleh pengguna motor dan penydia jasa dan akan menampilkan data yang diminta sesuai dengan data yang ada pada database sistem.

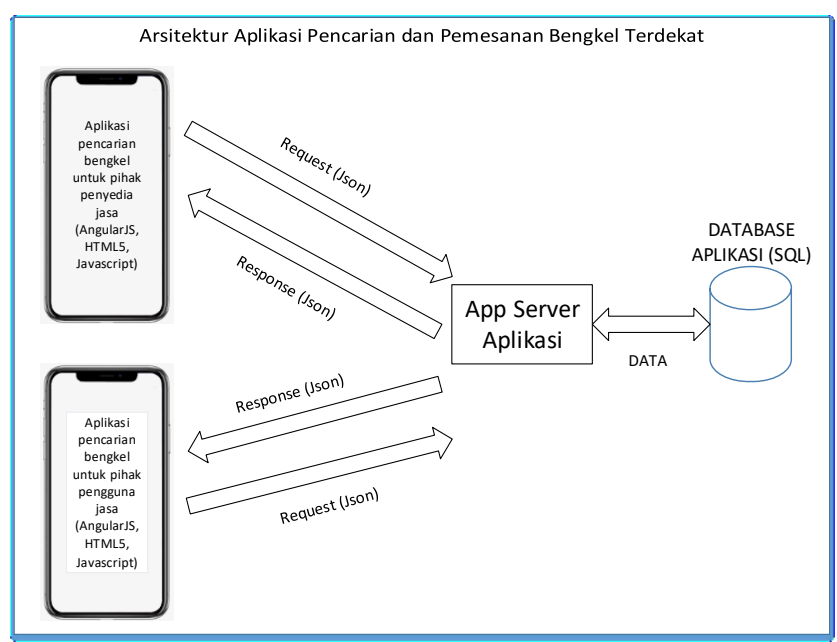

Gambar 1. Desain arsitektur sistem

Desain arsitektur yang terlihat pada Gambar 1 menggambarkan proses pada Aplikasi pencarian dan pemesanan Bengkel, bagaimana aplikasi terhubung ke database untuk menyimpan data dan menampilkan data. Data yang diminta oleh pengguna jasa merupakan data detail akun miliknya, data pesan pengguna dan data komentar mengenai bengkelnya. Sedangkan data yang diminta oleh pengguna jasa adalah data lokasi penyedia jasa, data komentar dan profil bengkel.

\subsection{Usecase}

Use case diagram pada Gambar 3 menggambarkan masing-masing proses yang nantinya dapat dilakukan oleh aktor, dimana aktor pada sistem sendiri terbagi menjadi 2 yaitu pengguna baru, pengguna motor dan penyedia jasa.

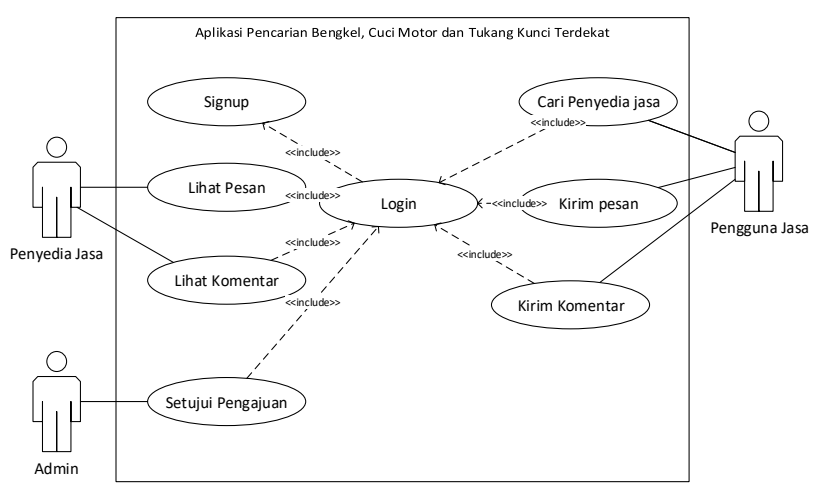

Gambar 2. Usecase Diagram

\subsection{ERD}

ERD menjelaskan model data yang akan digunakan dalam aplikasi bengkel bergerak berbasis android. Terdapat beberapa entitas yakni:

a. Entitas Bengkel dengan masing-masing atribut yakni id_bengkel, username, password, namaBengkel, nama_Pemilik, jenis_bengkel, alamat, No_hp, email, latitude dan longitude. Untuk password pada bengkel, diberikan fungsi hash yakni MD5 agar data lebih aman

b. Entitas LoginBengkel dengan masing-masing atribut yakni id, username dan password. Dimana untuk atribut username dan pasword diambil dari data bengkel.

c. Entitas Pengguna dengan masing-masing atribut yakni id_pengguna, username, password, nama, alamat, no_hp, email. Untuk password pada bengkel, diberikan fungsi hash yakni MD5 agar data lebih aman.

d. Entitas LoginPengguna dengan masing-masing atribut yakni id, username dan password. Dimana untuk atribut username dan pasword diambil dari data pengguna.

e. Entitas pesan dengan atribut id, id_pengguna, id_bengkel, nama_pengguna, nama_bengkel, jenis kerusakan, keterangan, waktu, longitude, latitude dan status.

f. Entitas komentar dengan atribut id, id_pengguna, id_bengkel, nama_pengguna, nama_bengkel dan komentar. 


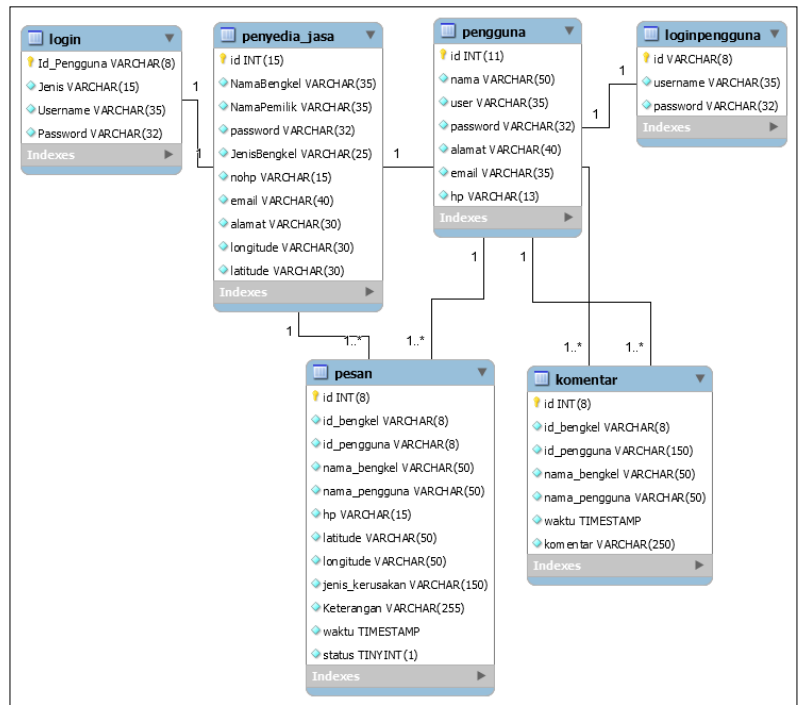

Gambar 3. ERD aplikasi pencarian bengkel, cuci motor dan tukang kunci

\section{HaSil dan Pembahasan}

\subsection{Implementasi Interface}

Pada implementasi sistem terdapat beberapa tampilan interface sistem berdasarkan pengguna sistem ini yang terdiri dari, pengguna motor dan penyedia jasa atau bengkel. Berikut hasil dari implementasi interface dapat dilihat pada Gambar 4 sampai Gambar 14.

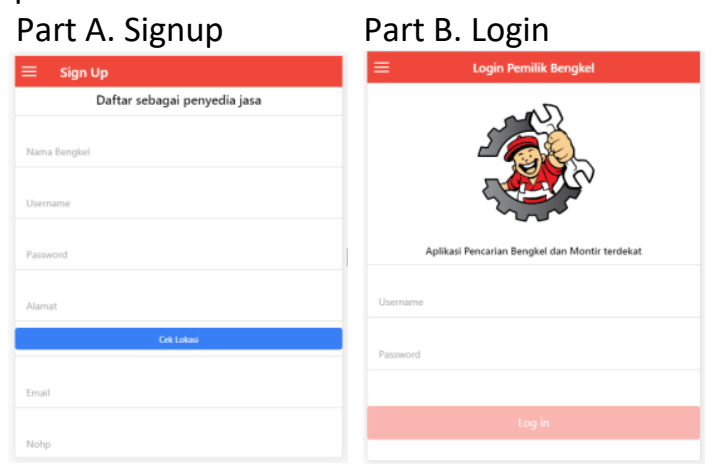

Gambar 4. Halaman SignUp dan Login

Halaman sign up merupakan salah satu pilihan yang diberikan saat pengguna baru saja membuka aplikasi. Sama seperti proses sign up atau pendaftaran pengguna pada umumnya, dimana terdapat form yang harus diisi oleh pengguna baik penyedia jasa maupun pengguna motor.

Sama seperti pengguna aplikasi pada umumnya, penyedia jasa juga harus melakukan login untuk tetap menjaga data-data privasi mengenai bengkel yang di kelolanya. Halaman beranda untuk pemilik bengkel berisi nama bengkel, rating dan komentar-komentar pengguna yang terkait dengan bengkel tersebut. Pada beranda bengkel terdapat 2 button yang aktif yakni button profil dan button pesan. Button profil akan membawa pengguna menuju halaman detail dari profil bengkel tersebut, dimana data detail tersebut dapat di perbaharui oleh pemilik akun. Sedangkan button pesan, akan membawa pengguna menuju halaman list pesanan yang masuk pada bengkel tersebut.

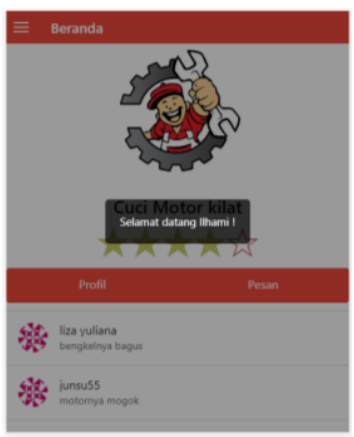

Gambar 5. Implementasi tampilan beranda untuk penyedia jasa

Halaman beranda untuk pemilik bengkel berisi nama bengkel, rating dan komentar-komentar pengguna yang terkait dengan bengkel tersebut. Pada beranda bengkel terdapat 2 button yang aktif yakni button profil dan button pesan.

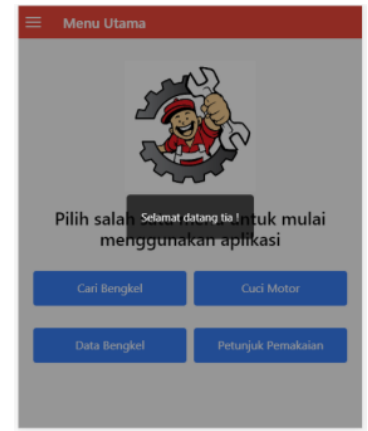

Gambar 6. Implementasi tampilan beranda untuk pengguna motor

Setelah pengguna melakukan login, maka pengguna akan dibawa masuk ke halaman beranda. Dimana pada halaman beranda terdapat 4 menu utama yang dapat digunakan oleh pengguna motor, yakni fitur cari bengkel,cuci motor, tukang kunci dan cara penggunaan aplikasi. 


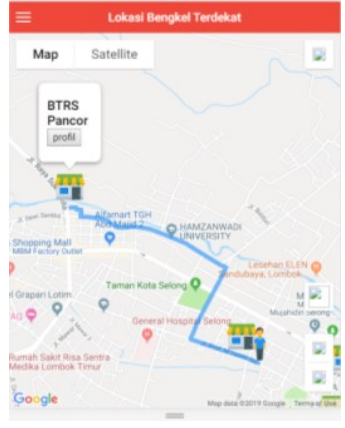

Gambar 7. Implementasi interface pencarian penyedia jasa

Halaman cari bengkel merupakan halaman yang menampilkan marker bengkel yang tersedia di sekitar pengguna motor saat itu. Pada saat marker di click, maka akan muncul keterangan berupa nama bengkel, alamat dan tombol menuju halaman beranda bengkel tersebut serta rute menuju bengkel tersebut. Maksud ditunjukkannya rute menuju bengkel tersebut yakni agar pengguna motor dapat langsung mendatangi bengkel yang diinginkannya bila jaraknya dirasa cukup dekat, tanpa perlu melakukan pemesanan montir terhadap pihak bengkel.

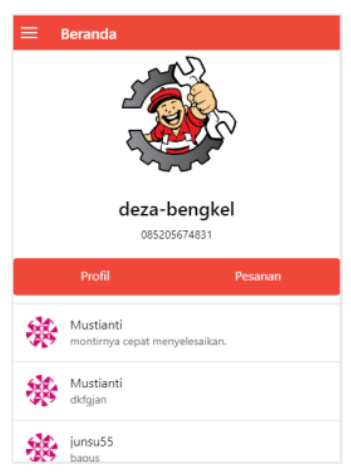

Gambar 8. Implementasi tampilan beranda bengkel

Setelah pengguna memilih salah satu marker bengkel, maka pengguna bisa masuk ke beranda bengkel tersebut dengan menekan tombol profil pada infowindow marker tersebut. Pada beranda, muncul beberapa komentar mengenai bengkel tersebut, dimana tujuan komentar ditampilkan agar dapat menjadi bahan pertimbangan untuk pengguna motor saat ingin melakukan pesanan terhadap suatu bengkel. Terdapat 2 opsi tombol yang dapat dipilih yakni tombol komentar dan tombol pesan.

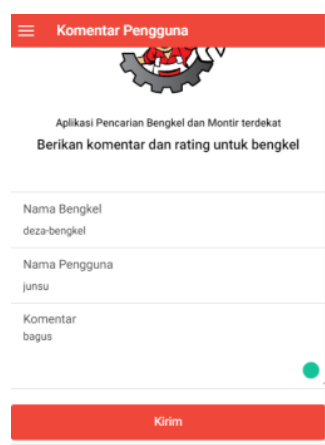

Gambar 9. Form mengirim komentar.

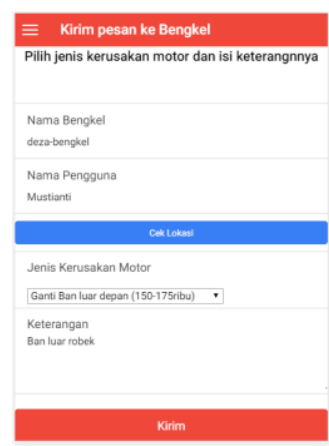

Gambar 10. Form mengirim pesan.

Setelah pengguna memilih salah satu tombol aktif, pengguna dapat mengirimkan komentar ataupun pesanan terhadap bengkel dengan mengisi form isian yang tersedia lalu mengirimkannya. Komentar yang terkirim akan muncul di beranda bengkel dan dapat dilihat oleh pengguna lain yang melihat beranda bengkel tersebut. Sedangkan pesan setelah dikirim hanya dapat dilihat oleh bengkel.

\subsection{Pengujian Sistem}

Terdapat 2 metode yang digunakan untuk pengujian yaitu metode MOS dan metode blackbox.

a. Pengujian Blackbox

Metode pengujian blackbox merupakan metode pengujian yang menguji fungs-fungsi di dalam sistem untuk untuk mengetahui apakah fungsifungsi yang ada sesuai harapan atau tidak. Hasil pengujian black box menunjukkan semua fungsi yang ada dalam sistem ini telah berjalan dengan baik.

b. Pengujian MOS

Pengujian MOS[13] digunakan untuk mengukur kesesuaian aplikasi berdasarkan pendapat subjektif dari pengguna Aplikasi Pencarian bengkel terdekat berbasis mobile dimana jumlah keseluruhan responden sebanyak 30 responden. Responden terdiri dari 2 jenis yaitu pengguna motor dan penyedia jasa bengkel dan 
cuci motor, dibuat 15 kuesioner untuk masingmasing jenis responden. Kuesioner dilakukan untuk mengetahui usability dari aplikasi pencarian bengkel yang meliputi learnability, efficiency, memorability, errors, satisfaction. Pengujian MOS dilakukan dengan cara mendemokan prototype aplikasi secara langsung kepada responden baik pengguna motor maupun penyedia jasa kemudian memberikan kuesioner sesuai dengan jenis responden. Adapun daftar kuesioner data.

TABEL I. DAFTAR PERTANYAAN KUESIONER UNTUK PENGGUNA MOTOR

\begin{tabular}{|l|l|}
\hline No & \multicolumn{1}{|c|}{ Pertanyaan } \\
\hline 1 & Aplikasi mudah digunakan? \\
\hline 2 & Cara pengoperasian aplikasi mudah di ingat? \\
\hline 3 & $\begin{array}{l}\text { Banyak terjadi kesalahan pemilik motor saat } \\
\text { mencoba mengoperasikan aplikasi? }\end{array}$ \\
\hline 4 & $\begin{array}{l}\text { Fitur cari bengkel, cuci motor dan tukang } \\
\text { kunci berjalan dengan baik. }\end{array}$ \\
\hline 5 & $\begin{array}{l}\text { Pemilik motor puas dengan fitur utama } \\
\text { aplikasi yang dirancangkan. }\end{array}$ \\
\hline
\end{tabular}

TABEL II. DAftar PeRtanyaAn Kuesioner Untuk Penyedia

\begin{tabular}{|l|l|}
\multicolumn{2}{c|}{ JASA } \\
\hline No & \multicolumn{1}{c|}{ Pertanyaan } \\
\hline 1 & Aplikasi mudah digunakan? \\
\hline 2 & Cara pengoperasian aplikasi mudah di ingat? \\
\hline 3 & $\begin{array}{l}\text { Banyak terjadi kesalahan pemilik bengkel saat } \\
\text { mencoba mengoperasikan aplikasi? }\end{array}$ \\
\hline 4 & $\begin{array}{l}\text { Fitur lihat pesan dan lihat komentar berjalan dengan } \\
\text { baik. }\end{array}$ \\
\hline 5 & $\begin{array}{l}\text { Pemilik bengkel puas dengan fitur utama aplikasi } \\
\text { yang dirancangkan. }\end{array}$ \\
\hline
\end{tabular}

Berdasarkan pertanyaan yang ada, responden diminta untuk menjawab dengan nilai-nilai tertentu antara lain:

1 = Sangat tidak setuju (STS).

2 = Tidak setuju (TS).

$3=$ Cukup $(\mathrm{C})$

$4=$ Setuju (S).

5 = Sangat setuju (SS).

Selanjuntya akan dihitung persentase jawaban yang diberikan pengguna di setiap pertanyaan. Persamaan (1) digunakkan untuk menghitung persentase nilai hasil kuesioner.

$$
\text { Persentase }=\frac{J}{N} * 100 \%
$$

dimana:
$J$ adalah total nilai jawaban responden pada setiap nomor, dan

$N$ adalah Jumlah responden.

Dengan menggunakan rumus persentase, perhitungan hasil jawaban responden dapat di lihat pada Tabel III, sedangkan grafik persentase jawabannya dapat dilihat pada gambar 11 .

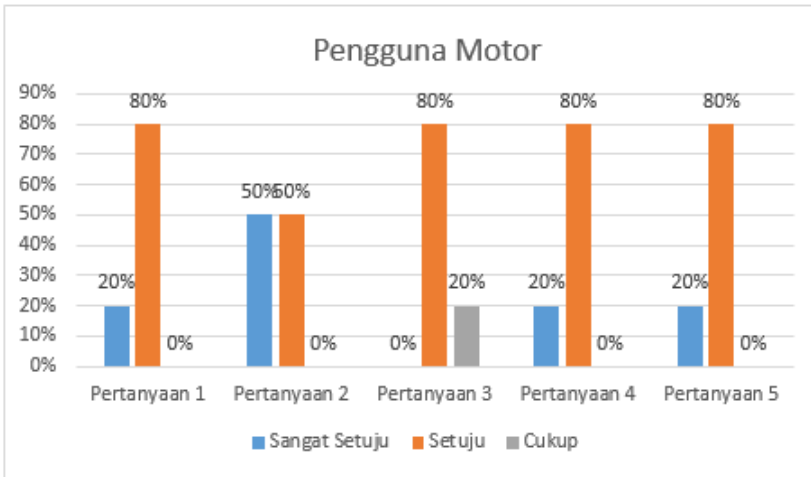

Gambar 11. Grafik jawaban responden pengguna motor

Gambar 11 merupakan grafik presentase jawaban kuesioner untuk setiap pertanyaan. Dari gambar tersebut dapat dilihat bahwa sebesar $20 \%$ menjawab sangat setuju dengan pertanyaan nomor 1 , lalu $80 \%$ menjawab setuju dari total 10 responden. Dapat dilihat bahwa sebesar $50 \%$ menjawab sangat setuju dengan pertanyaan nomor 2 , lalu $50 \%$ menjawab setuju dari total 10 responden. Dapat dilihat bahwa sebesar $80 \%$ menjawab setuju dengan pertanyaan nomor 3, lalu $20 \%$ menjawab cukup dari total 10 responden. Dapat dilihat bahwa sebesar $20 \%$ menjawab sangat setuju dengan pertanyaan nomor 4, lalu $80 \%$ menjawab setuju dari total 10 responden. Dapat dilihat bahwa sebesar $20 \%$ menjawab sangat setuju dengan pertanyaan nomor 5 , lalu $80 \%$ menjawab setuju dari total 10 responden.Berdasarkan persentase tiap pernyataan, maka dapat disimpullan persentase ratarata untuk setiap kategori kuesioner, adalah seperti Gambar 12.

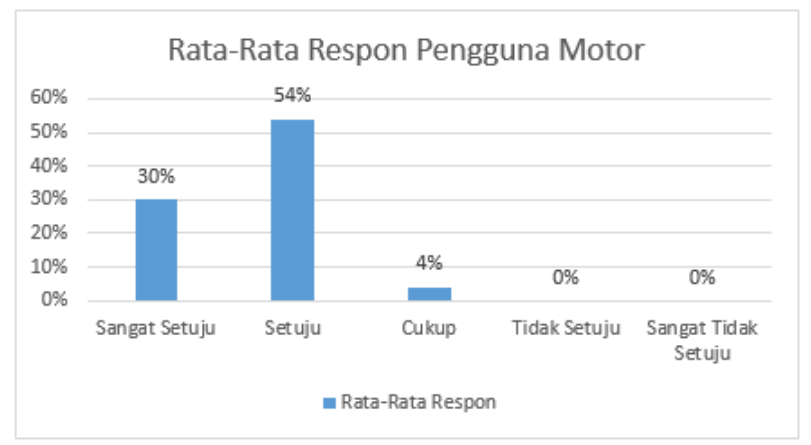

Gambar 12. Grafik rata-rata respon pengguna motor 
Gambar 12 grafik rata - rata persentase jawaban responden. Berdasarkan hasil Mean Opinion Score (MOS) menunjukkan bahwa rata-rata penili responden bernilai $30 \%$ pengguna sangat setuju, ! setuju dan $16 \%$ cukup. Untuk hasil perhitungan bagi penyedia jasa atau pemilik bengkel,dengan menggunakan rumus persentase, perhitungan hasil jawaban responden dapat dilihat pada Gambar 13.

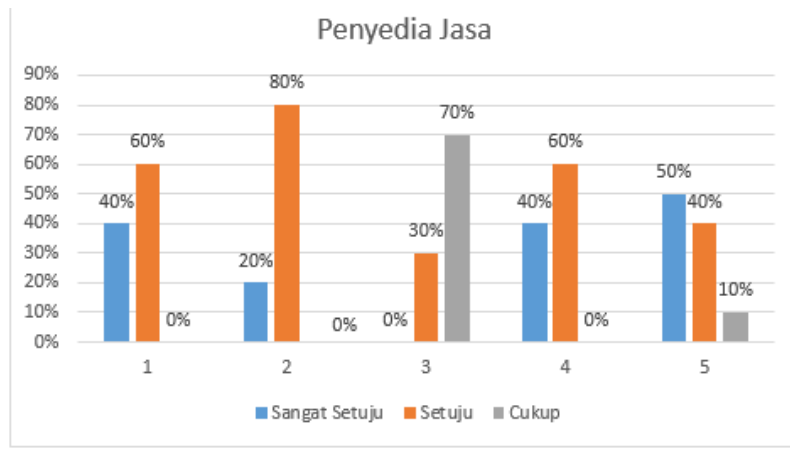

Gambar 13. Grafik jawaban responden penyedia jasa

Gambar 13 grafik presentase jawaban kuesioner untuk setiap pertanyaan. Dari gambar tersebut dapat dilihat bahwa sebesar $40 \%$ menjawab sangat setuju dengan pertanyaan nomor 1 , lalu $60 \%$ menjawab setuju dari total 10 responden. Dapat dilihat bahwa sebesar $20 \%$ menjawab sangat setuju dengan pertanyaan nomor 2 , lalu $80 \%$ menjawab setuju dari total 10 responden. Dapat dilihat bahwa sebesar 30\% menjawab setuju dengan pertanyaan nomor 3 , lalu $70 \%$ menjawab cukup dari total 10 responden. Dapat dilihat bahwa sebesar $40 \%$ menjawab sangat setuju dengan pertanyaan nomor 4, lalu $60 \%$ menjawab setuju dari total 10 responden. Dapat dilihat bahwa sebesar $50 \%$ menjawab sangat setuju dengan pertanyaan nomor 5 , lalu $40 \%$ menjawab setuju dan $10 \%$ cukup dari total 10 responden.

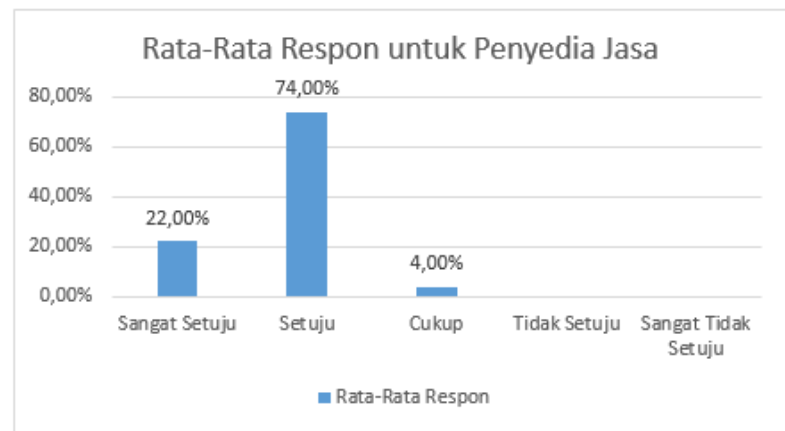

Gambar 14. Grafik rata-rata respon penyedia jasa

Gambar 14 merupakan grafik rata - rata persentase jawaban responden. Berdasarkan hasil Mean Opinion Score (MOS) menunjukkan bahwa rata- rata penilaian responden bernilai $22 \%$ pengguna sangat setuju, $74 \%$ setuju dan $4 \%$ cukup dari total 10 responden.

\section{Kesimpulan dan Saran}

\subsection{Kesimpulan}

Berdasarkan penelitian dan pembangunan sistem yang dilakukan, terdapat beberapa hal yang dapat disimpulkan, antara lain:

a. Dari proses analisa dan perancangan, didapatkan fitur yang dibutuhkan yaitu dapat menerima pesanan masuk, melihat komentar bagi penyedia jasa tau pemilik bengkel. Sedangkan fitur melihat bengkel yang ada di sekitar lokasi, melihat rute, mengirim pesanan dan komentar kepada bengkel merupakan fitur yang diperuntukan bagi pengendara motor yang menggunakan aplikasi.

b. Aplikasi Mobile Pencarian dan pemesanan bengkel dapat membantu mempermudah pencarian bengkel di sekitar lokasi pengendara motor yang sedang mengalami masalah dengan motornya dibantu dengan tampilan yang memperlihatkan rute menuju bengkel saat pengguna memilih salah satu bengkel yang diinginkan.

c. Dari hasil pengujian blackbox menunjukkan bahwa seluruh fungsi-fungsi fitur aplikasi Pencarian dan pemesanan bengkel berbasis mobile telah berjalan sesuai dengan sistem yang dirancangkan.

d. Berdasarkan hasil Mean Opinion Score (MOS) menunjukkan bahwa rata-rata penilaian responden pemilik motor bernilai 30\% pengguna sangat setuju, $54 \%$ setuju dan $16 \%$ cukup.

e. Berdasarkan hasil Mean Opinion Score (MOS) menunjukkan bahwa rata-rata penilaian responden penyedia jasa bernilai $22 \%$ pengguna sangat setuju, $74 \%$ setuju dan $4 \%$ cukup.

\subsection{Saran}

Terdapat beberapa saran yang perlu disampaikan berdasarkan hasil pembahasan pembuatan Aplikasi Pencarian dan pemesanan bengkel berbasis mobile, yaitu:

a. Untuk penelitian selanjutnya, peneliti bisa menambahkan filter pemilihan type dan merk motor pada saat melakukan pesanan terhadap 
bengkel sehingga bengkel dapat membawa alat yang lebih spesifik.

b. Memperluas target pengguna, misal untuk para tourist yang sering menyewa motor saat melakukan perjalanan dengan menambah option bahasa pada aplikasi.

\section{DAfTAR PUStaka}

[1] K. L. L. K. R. Indonesia, "Perkembangan Jumlah Kendaraan Bermotor Menurut Jenis, 1949-2017," 2018. .

[2] N. Farida, "Sistem Delivey Order Berbasis Android Pada AADS Yogyakarta," Publikasi_09.11.3242, p. 18, 2014.

[3] N. T. Z. Adi, "Membangun Aplikasi Layanan Pencarian Lokasi Kuliner Terdekat Di Yogyakarta Berbasis Android," 2012.

[4] H. S. Teddy Alhadiy Sami, Vivi Sahfitri, "Aplikasi Pencarian Lokasi Bengkel Motor Kota Palembang Berbasis Android Dengan Metode Mobile-D," Mob. MAP Explor. LOKASI BENGKEL DI PALEMBANG DENGAN GPS Berbas. Platf. ANDROID, pp. 1-6.

[5] W. D. Mustofa, "Perancangan Aplikasi Pencarian Bengkel Di Kabupaten Gunungkidul Menggunakan Global Positioning System (GPS) Berbasis Android," NASKAH Publ. Peranc. Apl. Pencarian Bengkel Di Kabupaten Gunungkidul Menggunakan Glob. Position. Syst. Berbas. Android, vol. 151, pp. 10-17, 2015.

[6] Y. Sakti, N. Rohhim, N. Rijati, and K. Kunci, "Rekayasa
Sistem Pencarian Bengkel Mobil Berbasis Web Responsif di Kota Semarang," Rekayasa Sist. Pencarian Bengkel Mob. Berbas. Web Responsif di Kota Semarang.

[7] B. Putera Perkasa, S. Putra Prasetiyono, M. Chairul Anwar, S. T. Irwansyah, and others, "Aplikasi Sistem Informasi Geografis Untuk Pencarian Bengkel Mobil Mazda Di Jakarta Berbasis Android," 2015.

[8] Y. D. Triyanti, "Aplikasi android untuk pencarian lokasi tempat ibadah di wilayah bekasi," Pros. Semin. IIm. Nas. Komput. dan Sist. Intelijen (KOMMIT 2014), vol. 8, no. Kommit, pp. 446-452, 2014.

[9] K. A. Wicaksono, "Aplikasi Pemetaan Lokasi Bengkel Ahass Kota Semarang Berbasis Android," 2013.

[10] A. A. K. A. C. W. I Made Widnyana, I Nyoman Piarsa, "Aplikasi Sistem Informasi Geografis Bengkel di Kota Denpasar Berbasis Android," Merpati, vol. VOL. 3, NO, no. 1, p. 26, 2015.

[11] I. H. S. SE, Panduan Praktis Merawat dan Memperbaiki Sepeda Motor. Gramedia Pustaka Utama, 2018.

[12] N. Safaat, Aplikasi Berbasis Android. Bandung: Informatika, 2013.

[13] S. Syaifullah, I. G. P. S. Wijaya, and A. Y. Husodo, "Sistem Informasi Kepuasan Layanan Administrasi Akademik Berbasis IPA (Importance Performance Analysis) Studi Kasus Fakultas Teknik Universitas Mataram," J. Comput. Sci. Informatics Eng., vol. 2, no. 1, 2018. 